Comparative Philosophy Volume 8, No. 1 (2017): 47-62

Open Access / ISSN 2151-6014

www.comparativephilosophy.org

\title{
MORAL PRACTICE IN LATE STOICISM AND BUDDHIST MEDITATION
}

\author{
MICHAEL GOERGER
}

\begin{abstract}
I argue in this essay that Stoic philosophers in the late Greco-Roman period utilized philosophical exercises and spiritual technologies similar in form to a meditative exercise currently practiced in Buddhism. I begin with an in-depth discussion of moral development in the late Stoa, focusing particularly on their theories of cosmopolitanism and oikeiōsis. These theoretical commitments, I argue, necessitated the adoption of exercises and practices designed to guide practitioners toward the goal of universal moral concern. Using insights gained from Buddhist practice, I identify passages in Stoic texts that call for and prescribe moral exercise. While much work in comparative philosophy compares the content of diverse philosophical theories, the form that these theories take can also be compared. Stoic philosophy was viewed as a "way of life" by many ancient philosophers, and thus their philosophical views share several formal characteristics with Buddhist religious practices. The primary good realized by this comparison, I conclude, is to outline the ways in which Greco-Roman philosophies can be enriched by reading these theories in light of the lived, practical traditions that characterize Buddhist thought.
\end{abstract}

Keywords: Stoicism, Buddhism, oikeiōsis, moral development, mettā, meditation

1.

In this essay I argue that a limited comparison between Buddhist meditative practices and Stoic ethics in the Roman period provides insight into Stoic practices aimed at moral development. Much comparative work in philosophy focuses on using the theoretical commitments and philosophical concepts employed within Western traditions to make sense of non-Western traditions. I take a somewhat different tack, using the moral practices and philosophical technologies of contemporary and classical Buddhism to deepen our understanding of Greco-Roman Stoicism. Both schools share a theoretical commitment to universal moral concern and both developed practices that guide students toward this goal. While direct textual evidence of Stoic moral practice is rare, practices in Buddhism, I argue, can be used

GOERGER, MICHAEL: Assistant Professor of Philosophy, Central Washington University, Washington, USA. Email: Michael.Goerger@cwu.edu 
to identify and reinterpret passages that describe Stoic moral practices. The end result of this work is both a better understanding of Greco-Roman Stoicism and a fruitful method of comparing Hellenistic philosophies with non-Western philosophical systems.

I begin by arguing in Section 2 that the Stoics viewed philosophy as a way of life, as a practical task as well as an intellectual enterprise. I then argue in Section 3 that the Stoics were committed to the development of universal moral concern. This ethical commitment is shared with both classical and contemporary Buddhism, and in Section 4 I explore the Buddhist tradition. I examine one meditative practice $-m e t t \bar{a}$ meditation - designed to develop universal love. In Section 5, I return to Stoicism and argue that the same technique used in metta meditation, re-identification of the target individual, is present in several Stoic texts. These passages, I argue, outline actual exercises practitioners should use to develop moral concern. I conclude in Section 6 with a discussion of the strengths and weaknesses of my methodology.

2.

In her landmark work The Therapy of Desire, Martha Nussbaum (1994) argues that Hellenistic moral philosophy is characterized by a medical analogy in which the practice of philosophy heals the soul just as the practice of medicine heals the body. That is, just as a medical doctor treats physical illness, philosophers treat psychological and emotional maladies. The Hellenistic philosophers viewed philosophy as a discipline or series of disciplines that could be used to treat grief, anxiety, and other misfortunes (c.f. Hadot 1981; Hadot 1995; Nehamas 2000). In what follows, I illustrate and defend this position through a close discussion of two representative passages from late Stoic authors. In both passages, the logic chopping and "quibbling" of some philosophers is contrasted with a practical engagement with philosophical truths. The first passage is drawn from Epictetus (55-135 CE); the second is taken from Seneca (4 BCE-65 CE).

\section{1}

In Discourse I.4 Epictetus asks how one progresses in philosophy. Epictetus believes that virtue leads to happiness, serenity, and an untroubled mind, and so he thinks progress in philosophy must lead to each of these things. As a student of philosophy, he says, you must discipline yourself so that you will, "neither fail to attain what you desire nor fall into what you want to avoid; in exerting your impulse to act and not act, that you may not be liable to error; in assent and the withholding of assent, that you may not be liable to be deceived (I.4.11)." The goal of intense philosophical study consists in using the knowledge gained through philosophy to transform one's life.

Epictetus draws an extended metaphor between a philosopher and an athlete to argue that philosophical knowledge must be used to reshape oneself (I.4.13-17). The athlete's goal is to build muscle and develop strength in order to become a more 
effective wrestler. Epictetus imagines asking the athlete if he has made progress toward this goal. The athlete replies by pointing to his weights, showing that he possess the equipment needed to develop strength. Epictetus thinks that this is a ridiculous response; he doesn't want to know if the athlete has acquired the correct equipment, but if he has used that equipment to develop his abilities. As it stands, few athletes would mistake the means (the weights) with the end (developing strength) in this way. The athlete is then compared to a student of philosophy. The student is also asked to demonstrate her progress. Like the athlete, she points to her books, saying, "Take the treatise On Impulse [a famous Chrysippian treatise] and see how thoroughly I have read it (I.4.14)." Epictetus responds, "That is not what I'm looking for, slave, but how you exercise your impulse to act and not act (I.4.14)." While the student may have carefully read the treatise, this does not necessarily show that she has put the treatise into practice and mastered her own impulses. Epictetus believes that many students of philosophy make this mistake, confusing the goal of philosophy with the means used to obtain that goal.

Epictetus concludes that you should, "Never look for your work in one place and your progress in another (I.4.19)." The student engages in intellectual work. She studies diligently, stays up late into the night, and devotes herself to the mastery of arguments. Yet, progress lies in her ability to use this knowledge to control her impulses and transform her desires. This is the material with which she should work. The student is like an individual who, trying to get fit, collects gym memberships and exercise equipment not realizing that progress is not found in the equipment but in using it. She may acquire many ideas and master complicated philosophical theories, but until she applies these theories to her own life, she will not make progress as a philosopher.

\section{2}

Epictetus' views are echoed by Seneca in a second representative passage. In the $48^{\text {th }}$ letter to Lucilius, Lucilius asks Seneca for his opinion on a paradox in the philosophy of friendship. Seneca chides him, saying, "What you have to offer me is nothing but the distortion of words and splitting of syllables. It is clear that unless I can devise some very tricky premises and by false deductions tack on to them a fallacy which springs from the truth, I shall not be able to distinguish between what is desirable and what is to be avoided (48.5)." And then, "I am ashamed! Old men as we are, dealing with a problem so serious we make play of it (48.5)." Lucilius' concerns about friendship are important, but Seneca finds his attempt at logical analysis unworthy of philosophical engagement. The purpose of philosophy is not to solve paradoxes, but to provide guidance and, in the case of the Stoics, to develop one's faculties of desiring, choosing, and acting. "Philosophy offers council," Seneca concludes while doubting that Lucilius' style of inquiry will help him live a better life (48.8).

Seneca's argument is more forceful than that offered by Epictetus. After asking whether arguments alone will relieve the student's burdens, he writes, "Would that I could say that they were merely of no profit! They are positively harmful (48.10)." 
Lucilius is so entangled in arguments, definitions, distinctions, and objections that he fails to examine his own desires, fears, and aversions and does not work to correct them. Further, by disconnecting the arguments and distinctions from the life he lives, Lucilius deprives philosophy of its characteristic value. Ensnared by argument, he forgets to examine himself.

Other letters contain similar statements which favor philosophical development through practice as well as study. For example, in the $18^{\text {th }}$ letter Seneca sets out the following task to help Lucilius control his desire for wealth: "Set aside a certain number of days, during which you shall be content with the scantiest and cheapest fare, with coarse and rough dress, saying to yourself all the while: "Is this the condition I fear?" (18.5)." Self-denial, a frequent prescription in Seneca's letters, helps one see that the desire for wealth and the fear of poverty are irrational. Three or four days of self-imposed poverty are a "test" and "experiment" by which philosophers "practice our strokes on the "dummy" (18.8)."

The purpose of these exercises is to break the grip of desire and aversion on the psyche. Lucilius is wealthy, and Seneca does not advise that he dispose of his wealth. Instead, he hopes that through practice, Lucilius will come to live with his wealth, "dauntlessly," which can happen only "by persuading yourself that you can live happily without it as well as with it...(18.13)." The goal of philosophy is practical, to discipline one's desires and aversions, and this practical goal will not be met until one puts philosophical knowledge into practice in one's own life. It is one thing to know that it is irrational to fear poverty, but quite another to no longer fear it.

Both Epictetus and Seneca explicitly claim that Stoic philosophy involves work (c.f. Sellars 2006). While philosophical knowledge is important to the StoicsEpictetus claims that philosophical theories teach us "the things from which serenity arises and tranquility comes to us (I.4.28)"- - one cannot live well without putting this knowledge into practice. Merely reading the treatise On Impulse or solving a paradox regarding friendship will not make the theory efficacious in one's life. Discipline, practice, and exercise are required if progress is to be made, and study that doesn't include such practice is useless. If one desires to obtain the tranquility promised by Stoic philosophy, one must examine and discipline one's desires, thoughts, and actions in light of the arguments and teachings of philosophers. And so one tries to sleep on a hard bed, to remain sober while the mob is drunk during Saturnalia, to control one's emotions when consoling a grieving friend, and to eat simple food when indulgences are available. In each case one is disciplining oneself, practicing against the dummy, and doing the work of philosophy.

I now turn to the Stoic view that all individuals, regardless of rank, title, or position, are members of a common community and owed equal moral concern. This view is entwined with their support of cosmopolitanism - the ethico-political view that all individuals are members of one community or polis (Kleingeld \& Brown 2013; c.f. Appiah 2006 and Nussbaum 2002). Seneca writes, 
There are two commonwealths - the one, a vast and truly common state, which embraces alike gods and men, in which we look neither to this corner of the earth nor to that, but measure the bounds of our citizenship by the path of the sun; the other, the one to which we have been assigned by the accident of birth (de Otio 4.1).

Seneca here argues that every individual is bound not only to those who live in the same physical polis, but to all those who fall under the "path of the sun." One is obligated to serve the human community whenever doing so is possible, and when humanitarian actions of this type are not possible one should serve those nearest to one (Seneca, de Otio 3.5). Cosmopolitanism thus expands the ethico-political community (the polis) to include the entirety of the universe (the cosmos). As a result, some degree of moral concern is owed to all other human beings.

The Stoics termed the process by which individuals develop moral concern for other rational beings oikeiōsis (Pembroke 1971). The term is difficult to translate. The root word, the noun oikos, means 'house' or 'household' and includes those persons who belong to the household. Annas $(1995,262)$ suggests translating the word as "being akin to" or "familiarization," which suggests both "the notion of family and that of being close to and coming to belong to." In the Stoic context, the idea central to oikeiōsis is that one expands one's metaphorical household to include those who are normally excluded from it. It is, "the process by which we recognize our natural affinity first to ourselves and subsequently to various features of our environment (Blundell 1990, 221)." The Stoic theory of oikeiōsis is quite complex and a full discussion is not possible here. Instead, I focus on those aspects of the theory most germane to my thesis and draw heavily on primary texts. Several lengthy treatments are available for readers desiring a more complete understanding (c.f. Annas 1995 and Engberg-Pedersen 1990).

The most complete statement of the Stoic theory of oikeiōsis is found in Book III of Cicero's dialogue De Finibus. Cato argues that universal moral concern arises from considerations about what one has most reason to do. He begins:

Every animal, as soon as it is born (this is where one should start), is concerned with itself, and takes care to preserve itself. It favors its constitution and whatever preserves its constitution, whereas it recoils from its destruction and whatever appears to promote its destruction (de Fin. 3.16).

Cato goes on to claim that concern for self-preservation naturally develops as an individual grows older. Over time, one begins to view oneself as a rational person. Thus, what is good for oneself is to act as a rational person would act. Reason instructs one to pursue virtue which will lead one to one's own good. The agent thus begins to engage in virtuous action because it is (instrumentally) good to do so (de Fin. 3.21). At this stage her moral concern remains egocentrically oriented toward her own good as a rational person.

At the center of this argument is the observation that individuals naturally care about that which is viewed as part of or as belonging to oneself. For example, one is 
initially concerned for one's body because it is one's own body rather than because it is a body as such. Quite naturally then, Cato states at 3.62, "we are impelled by nature itself to love those to whom we have given birth." Children are a part of their parents in the biological sense, and it is thus natural for parents to be concerned with the welfare of their children. However, while parental love is an extension of self-love, it is other oriented. Parents love their children for their own sake, but love this child because it is theirs. For Cato, parental love constitutes the first step outside of the sphere of egotistical concern. Though still rooted in concern for one's self, the self is expanded to include the children. ${ }^{1}$

Concern for unrelated others comes about when the rational agent realizes that, "the very fact of being human requires that no human being be a stranger to others (de Fin. 3.63)." In order to support this point, Cato utilizes a familiar metaphor. He says,

Some of our body parts - for example our eyes and ears - are as it were created just for themselves. Others - for example legs and hands - also enhance the utility of the other parts $[\ldots]$ Yet the ties between human beings are far closer. Hence we are fitted by nature to form associations, assemblies, and states (de Fin. 3.63).

Like the varied parts of a body, it is in the nature of human beings to come together to work for the common aims of the common body. This is true of "associations, assemblies, and states," as well as the entire human community. Says Cato, "Nature has given bulls the instinct to defend their calves against lions with immense passion and force. In the same way, those with great talent and the capacity for achievement [...] have a natural inclination to help the human race (de Fin. 3.66)." Each of us, in so far as we are rational, ought to work for the "common advantage and welfare of all (de Fin. 3.65)." When one has completely developed one's rational agency, one no longer views oneself as a single individual among other individuals, but as a part of the whole human community.

What I have outlined above is the Stoic theory of moral development. This theory shows us that it is rational to view each individual as a member of a common body and to respect that individual as such. However, a Stoic like Epictetus or Seneca would now expect a student to begin to live this way, to actually treat all other individuals as members of the same body. For the sake of comparison, this is like demanding that Kantian philosophers live their lives in accordance with the Categorical Imperative or that Utilitarians live according to the Principle of Utility. The Stoics thus face a problem. They have a theoretical commitment to universal moral concern, but need to find practices that will develop this concern in the student.

\footnotetext{
${ }^{1}$ Stoic views of the self provide another interesting point of contact for comparative analysis. Unlike Buddhist theories of 'no self' the Stoics remain committed to a metaphysical self. However, I believe that one could argue that the Stoic conception of self is not egocentric because, as the theory of oikeiosis shows, the 'self' can include other individuals. Perhaps, then, the Stoic expansion of the self is similar to deflationary accounts of the self in Buddhism. See Sorabji (2005) for an overview of both traditions.
} 
4.

I will now argue that by examining how classical and contemporary Buddhists surmount the same problem, we can identify similar practices in Stoic philosophy. Buddhism, which shares with Stoicism the goal of universal moral concern, contains practices designed to generate a universally loving state. In particular, I will focus on metta $\bar{a}$ meditation. This form of meditation was developed within the Theravadān tradition, but is now practiced by Buddhists aligned with several different schools. ${ }^{2}$ The purpose of the meditation is to develop in practitioners the form of universal love required by Buddhist teachings.

In the Karaniya Mettā Sutta (2004), his "Hymn of Universal Love," the Buddha instructs his followers to cultivate mettā for all creatures of the earth. Mettā is a Pali word most commonly translated as 'loving-kindness.' The word is also often translated as 'friendliness', 'benevolence', or simply 'love'. Central to the sense of the word is a love that is entirely altruistic and not self-seeking (Harvey 2007; Salzberg 1995). After describing the all-encompassing nature of this task, which will not exclude,

weak or strong without exception,

long, large,

middling, short,

subtle, blatant,

seen $\&$ unseen,

near \& far,

born \& seeking birth (14-20)

the Buddha says that,

As a mother would risk her life

to protect her child, her only child,

so should one cultivate a limitless heart

with regard to all beings (26-29).

The wise person "who wants to break through to the state of peace (2)," and achieve "sublime abiding (38)" must take on the task of cultivating mettā for all living beings.

Just as the Stoics recognized that the Greek mind is familiar with the ethicopolitical relationships that characterize a polis and argued for the expansion of those relationships, the Buddha advocates a universal family in which a mother's love is extended to all beings. In both cases, the universal concern is not a new form of concern for others - it is not unique in type - but is instead a form of concern with

\footnotetext{
${ }^{2}$ My aim in this section is to discuss Buddhist practice as opposed to the beliefs and commitments of Buddhists of any single school. While I draw from both classical and contemporary sources and several traditions, the practice of mettā meditation is similar among these authors. Readers wanting a better understanding of the differences between various traditions should see Harvey (2000).
} 
which most are familiar. This familiar relationship, both schools claim, must be extended to strangers, foreigners, and the like; a relationship that is usually reserved for a select few forms the foundation for the type of relationship that one should expand to all others. Thus, while Stoicism and Buddhism appeal to different foundational relationships, the structure of their practices is quite similar.

As with the Stoics, cultivating mettā for all beings requires practice rather than a simple intellectual commitment. Mettā meditation is one practice which developed in response to this need and guides the practitioner as she pursues a universally loving state (c.f. Mills 2004). The process was codified in the fifth century CE by Buddhaghosa, an important Theravadān commentator on the Pali canon, in his work The Path to Purification (Buddhaghosa 1976). Buddhaghosa instructs the practitioner to purify his or her mind of hostility before beginning to "break down the barriers by practicing loving-kindness over and over again, accomplishing mental impartiality towards the four persons, that is to say, himself, the dear person, the neutral person, and the hostile person (IX.40)."

Mettā meditation is practiced today and contemporary Buddhist teachers ${ }^{3}$ generally describe the practice as follows: after achieving a state of meditative awareness the practitioner visualizes someone whom she already loves. This is most often the practitioner herself but can also be the practitioner's mother. ${ }^{4}$ She then repeats a mantra which bestows mettā upon the target person such as "May I be happy. May I be safe from internal and external dangers." She visualizes herself and "repeat[s] these phrases over and over again, letting the feelings permeate [her] body and mind (Kornfield 2002)." This meditation is practiced daily for several weeks. When the practitioner feels that her bestowal of metta upon herself is genuine and that she really does wish happiness and safety unto herself, she begins the exercise again visualizing a 'benefactor,' a person for whom she already feels love and kindness. Traditionally, the benefactor is the practitioner's teacher. Again, she repeats the mantra and continues to do so for several weeks or months until her bestowal of metta is genuine. Slowly, one person at a time over the course of many years, the process is continued. Next comes mettā toward friends, then community members, and then strangers. Finally, one extends mettā toward one's enemies. Throughout the meditative practice, the practitioner works to extend a genuinely compassionate wish to the target of her practice, only moving on when she feels that her mental states are in line with the words she utters.

Successful mettā meditation requires one to analyze and consider the barriers to $m e t t \bar{a}$ that need be broken if metta $\bar{a}$ is to be cultivated. It is easy to cultivate

\footnotetext{
${ }^{3}$ Metta meditation is a popular topic in contemporary western Buddhism. For the sake of consistency, my discussion here focuses mainly on the meditations described by American Theravadān Buddhist teacher Jack Kornfield (2002, 117-120). Another source informing my discussion is the Dalai Lama's (2005) Tibetan text. Salzberg (2002) provides a more extensive overview of mettā and its role within the Buddhist tradition.

${ }^{4}$ Therevadā and Mahāyāna teachers of mettā meditation often differ in whom they recommend as the first target person, with Therevadā often recommending the self and Mahāyāna often recommending that one start with the mother. See Harvey 2000, 107-08.
} 
compassion and loving kindness toward those for whom one usually possesses a loving state, but much harder as one moves to strangers and enemies. The exercise forces one to understand the limitations one currently places on moral concern and to expand one's concern despite those limitations. One common strategy for cultivating metta toward those to whom one is negatively disposed is to imagine that person as a child or as a parent (Dalai Lama 2005, 51-65). This procedure removes the focal person from the context in which one normally encounters him and forces the practitioner to view him as an entity capable of loving and being loved. The aim, only rarely achieved after a lifetime of practice, is to possess the positive disposition toward all living beings that a mother possesses toward her children.

The practice of metta meditation is frequently engaged in for many years, with the hope that one will develop a universally altruistic attitude. Empirical studies demonstrate that the exercise is effective in just seven weeks. That is, individuals who engage in mettā meditation even for a brief period of time do in fact become more altruistic and compassionate (Fredrickson et. al. 2008). Empirical studies such as these are important for two reasons. First, they show that meditative practices are effective. Second, they show that such exercises bridge the gap between theory and practice. The universally loving attitude expressed by the Buddha above can be developed provided that the practitioner engages in exercises designed to bring that state about.

5.

No extant evidence shows that the Stoics developed anything nearly as robust as metta meditation. ${ }^{5}$ However, I do believe that the Stoics utilized many of the same techniques in order to develop universal moral concern. My aim in this section is twofold. First, I will argue that the form of universal moral concern advocated by the Stoics is quite similar to the form of universal love advocated by the Buddha. Second, I will discuss the Circle of Hierocles in depth and outline two other passages which articulate moral exercises and practices similar in form and content to mett $\bar{a}$ meditation.

At first glance it may seem that Stoicism requires individuals to treat everyone with complete impartiality, abandoning the superficial differences and roles (mother, sister, cousin, etc.) that often influence our behavior toward others. Annas (1995, 262276) advocates this reading, trying to make sense of Stoic universal concern while at the same time noting that the Greeks had no word for our modern notion of impartiality. She argues that the theory of moral development produces a tension in Stoic moral theory between partiality owed to particular persons and complete moral impartiality. For example, the special and partial relationship one has with one's mother is "diluted" as one comes to treat mother, aunt, and stranger the same. This

\footnotetext{
${ }^{5}$ While my discussion focuses mainly on the reconstruction of ancient Stoic practice, contemporary Stoics have begun to construct similar exercises. See Stockdale (1993), Irvine (2008), and Holiday (2016) for more information about the current movement to revitalize Stoicism.
} 
tension is well known even in contemporary ethics (Nagel 1986; Wolf 1992), and it is not surprising that the Stoics encounter it as well.

Stoicism is a diverse school of thought and my remarks are limited to Stoics writing in the late Greco-Roman period, ${ }^{6}$ but among those authors, I believe there is ample textual evidence that speaks against the above reading (c.f. Sorabji 2000). Epictetus, for example, places great importance on the roles individuals play. In Discourse II.10, he asks students to "examine who [they] are," before they act. The student will find that "in the first place, [he is] a man, that is, a being in whom there is nothing more sovereign that his power of choice...(II.10.1)." He then lists other roles that the student may play: son, brother, city councilor, youth, old man, and so on. He says, "Each of these names, if rightly considered, always points to the acts appropriate to it." Though many over-emphasize roles and titles and underemphasize their common humanity, Epictetus does not argue that we should favor the human role over all others. Instead, one must be a brother and a human being, a councilor and a human being. He does not believe that universal moral concern is incompatible with the formation of particular moral relationships.

Seneca places a similar emphasis on roles. He considers a case in which a young man has been disinherited by his father. How should the young man act? As a son would act, Seneca claims. Again we find a connection between appropriate action and the roles one plays. The 'human' role is emphasized so frequently in Stoicism because, living as sons and fathers, aunts and cousins, we forget to act as a human being should act. Still, there is little evidence to suggest that the late Stoics believed that universal moral concern required absolute impartiality. Instead, it seems to require that one treat each person as our varied roles demand. To erode the moral importance of being a son or to erase that role in favor of complete impartiality is antithetical to the Stoic moral project.

The Stoics should be read as advocating an other-oriented concern similar to familial love. Blundell (1990) argues that discussions of oikeiōsis in ancient texts raise concerns similar to those that occur in discussions of familial love (philia), and at some points she speaks of oikeiosis in ways that suggest that the process expands love. For instance, she says, "The other regarding face of oikeiosis goes beyond this, however, to embrace concern of the other for their own sake. That is, we should be concerned for others...out of a disinterested concern for their well-being (222)." Many philosophers have closely connected the possession of a disinterested concern for well-being with loving another (e.g. Frankfurt 2004 and Helm 2010). Thus, while oikeiosis is a process by which one can expand moral concern and though the Stoics never identified the expansion of love as the goal of this process, if the common analysis of love is correct, then the Stoics were advocating the expansion of a

\footnotetext{
${ }^{6}$ In this essay I focus on Stoicism as articulated by philosophers during the Roman period primarily because these philosophers left behind a large number of extant writings. Further, it is generally argued that late Stoic figures were more concerned with the practical implications of Stoicism than earlier figures. It is not my intention to make a contribution to that debate here. Gill (2006) and Sorabji (2005) both provide excellent discussions of how the late Stoics differed from their predecessors while remaining committed to the Stoic philosophical project.
} 
disinterested, other-regarding concern similar to that articulated by Buddhism.

I will now turn to three passages in which Stoic philosophers articulate meditative exercises similar to mettā meditation.

\section{1}

The $2^{\text {nd }}$ century CE Stoic philosopher Hierocles, provides an image that helps to illustrate the above points. He imagines each individual as circumscribed by many concentric circles. At the center stands the agent. Surrounding him, in the first concentric circle, are his parents and siblings. The second circle contains extended family members, the third community members, and so on. As we move away from the center of the circle our moral concern naturally decreases. Hierocles instructs us to "draw the circles somehow towards the center, making all human beings more like our fellow city dwellers, and so forth (Stobeaus, Flor. 84.23)." Many contemporary philosophers have found Hierocles' way of conceptualizing the cosmopolitan project useful; philosophers as disparate as Martha Nussbaum (2002) and Peter Singer (2011) have utilized his image in their work.

Hierocles next suggests an exercise that "would stimulate and intensify the drawing in of the circles we have suggested." What is his 'treatment' or 'tonic'? He instructs students to begin to call uncles and aunts "mothers" and "fathers," to call cousins "siblings", and so forth. Presumably, this change in how one labels others is an exercise or "psychological mechanism" intended to reshape one's moral concern (Annas 1995, 267; c.f. Sorabji 2000, 222). The passage describes a practice designed to bring about the psychological state required by Stoic moral theory. One is to literally label and think about one's cousins as siblings in order to re-understand the relationship one has with them. Over time, this change in label should result in a change in moral concern as one becomes just as concerned for one's cousins as one is for one's siblings. This process is repeated for relatives, community members, and then strangers and foreigners as well.

The similarities between Hierocles' Circle and mettā meditation are quite obvious. As noted, in mettā mediation a frequent instruction when practicing with those toward whom one finds it difficult to extend love is to imagine the target individual as a child, a mother, etc. The point of this instruction is to upset one's understanding of the person and to see him in a different light, breaking down old identities and replacing them with new ones. Hierocles suggests a similar practice, and the image of the concentric circles suggests an exercise by which the practitioner implements changes and makes progress. When Hierocles suggests that we call our friends 'brother' and our aunts 'mother,' he is suggesting an exercise by which we might erode some of the barriers to more expansive moral concern. The change in label is meant to bring about a change in thinking which will, one hopes, reshape the direction and scope of one's moral concern.

I call this process, common among the Stoics, "re-identification." An individual for whom one does not experience moral concern is re-identified as an individual toward whom normally does experience moral concern. The moral concern for the 
latter individual is then projected onto the former individual. In this case, cousins are re-identified as siblings so that the concern one feels toward siblings can be extended to cousins. The process is also found in mettā meditation wherein the love one possesses for oneself is extended to close others, neutral persons, and enemies. In both Buddhism and Stoicism teachers argue that by working to alter the way we think about another, we can begin to reshape our concern for that person.

\section{2}

A less obvious example of re-identification is suggested in a famous passage by Marcus Aurelius. He writes:

Say to thyself at daybreak: I shall come across the busy-body, the thankless, the overbearing, the treacherous, the envious, the unneighborly. All this has befallen them because they know not good from evil. But I . . can neither be injured by them - for no one can involve me in what is debasing - nor can I be angry with my kinsman and hate him. For we have come into being for co-operation, as have the feet, the hands, the eyelids, the rows of upper and lower teeth. To thwart one another is against nature; and we do thwart one another by showing resentment and aversion. (Meditations II.1, emphasis added)

Marcus makes two suggestions in this passage. First, we must remember that those who annoy us are human beings and as such they are often misled as they choose between good and evil. Few claims are stressed more often in late Stoic writings; human beings make mistakes and often do so unintentionally. Second, he suggests that we come to view those who bother us as essential parts of the whole. To hate them and attempt to thwart them is to go against nature, for it is to disregard a part of the human community. Our enemies are thus no longer viewed as enemies but as misguided individuals with whom we must cooperate.

Marcus is advocating a philosophical exercise in this passage. While the passage is not ordinarily linked to moral development in the late Stoa, it suggests that one engage in a daily practice designed to reshape one's perceptions of the individuals that surround one. Given the emphasis on moral exercise in the late Stoics, Marcus' exhortation to "Say to yourself at daybreak...." prescribes a mantra that should be repeated daily. He believes that ordinary barriers between individuals can be broken down through radical re-identification and the repetition of such mantras. The passage, though perhaps not describing a 'meditative' practice at first glance, suggests that one repeat mantras and re-label others in ways quite similar to the meditative practices described in Section 4 above.

\section{3}

Seneca, a man obsessed with self-experimentation and practicing upon his own life, gives similar advice to one who finds himself too high and mighty to dine with a slave. He writes (in a bit of dialogue): “"They are slaves,' people declare. Nay, rather 
they are men. 'Slaves!' No, comrades. 'Slaves!' No, they are unpretentious friends. 'Slaves!' No, they are our fellow-slaves, if one reflects that Fortune has equal rights over slaves and free men alike (Ep. Mor. 47)." Again we see a push toward reidentification - a stripping down of one identity in order to replace it with another. The slave is a human being and as such deserves to be treated as a human being. He is neither superior nor inferior to the Stoic practitioner, but simply plays a different role in the cosmic drama. Each of us has our own masters, Seneca emphasizes, and is enslaved in our own way.

These three passages, the second and third rarely read as recommending or illustrating meditative exercises, each engage the Stoic student in a process similar to $m e t t \bar{a}$ meditation. As already noted, I think it unlikely that the Stoics developed meditative practices as complex or intense as those developed by Buddhist schools. However, the late Stoics and many schools of Buddhism embrace a similar theoretical commitment - the generation of universal moral concern — and placed great emphasis on practical outcomes over intellectual achievement. It is thus reasonable, I think to read these passages as recommending practical exercises to their readers. The ongoing use of metaphor, mantras, and re-identification makes little sense otherwise; absent a practical goal, the theoretical structure is not enriched by the representative passages.

6.

I have argued that we can gain insight into Stoic moral practice by considering similar practices in classical and contemporary Buddhist thought. It is frequently remarked that Stoicism is as much a "way of life" as it is a philosophical system. Less frequently, however, do we appreciate what this means for our interpretation and analysis of a school of thought that was, in many ways, comparable to contemporary lived religions. Stoic philosophy was not simply studied by ancient philosophers. One would not call an individual who had spent decades studying Buddhism a Buddhist unless she also practiced Buddhism. Her extensive knowledge is not sufficient to be a practitioner of the religion (Keown 2013, 5-7). Similarly, Epictetus, Seneca, and Marcus Aurelius self-identified as Stoics, as individuals who practiced Stoicism as opposed to those who merely studied it. Thus, we must treat the ancient Stoics not just as thinkers but also as practitioners, and we must read their writings not just to understand their thinking, but also to understand the form of life they lived and recommend.

When we examine the texts from this angle, we see a set of philosophers whose work was based in experience as much as intellect. They sought to practice what they preached and were not satisfied with argumentative quibbling. In this, Stoic thinkers have a great deal in common with many Buddhist thinkers. I hope that the above discussion demonstrates the need for more comparative work between Hellenism and many schools of Asian thought, with a greater emphasis on the practices and forms of life these figures advocate. A complete understanding of Stoicism requires an understanding of what it meant to live as a Stoic, and those Asian religious traditions 
in which the line between theoretical philosophy and practical life is much thinner provide excellent examples of how philosophical systems of this type function.

Of course, comparative work must be cautiously undertaken. Despite many similarities, Stoicism and Buddhism are diverse systems in their own right which developed on opposite sides of the globe over the course of many centuries. However, while I have allowed insights from Buddhism to shape my interpretation of Stoicism, I have grounded my claims about Stoicism in extant Stoic writings. My methodology suggests that similar theoretical commitments, in this case commitments to universal moral concern and to a lived philosophy, result in similar moral practices. I have placed before the reader passages that support this view.

Further, I hope that by taking Stoic philosophers at face value, one comes to see that they often have more in common with contemporary religious traditions than with much of the Western philosophical tradition. Self-professed doctors of the soul, these philosophers were not content with an understanding of the world and humanity's place within it (c.f. Nussbaum 1994). Instead, they sought to rescue their students from the vagaries of the human condition. This practical goal separates the late Stoics from figures, both ancient and modern, who view philosophy as a process by which insight is gained and knowledge is accumulated and systematized. The Hellenistic philosophers, particularly the Stoics, place a remarkable emphasis on the life of the philosopher, and their work undermines any firm distinction between theory and practice. To ignore this emphasis is to ignore much of what makes their work unique.

At the same time, and this must be stressed, the Stoic philosophers are philosophers in the Western tradition, and the pursuit of truth was central to their understanding of philosophy. The late Stoics perhaps occupied one end of a spectrum, placing less of an emphasis on the theoretical underpinnings of their theories and more on their salvific mission (c.f. Gill 2006 and Sorabji 2005). In approaching these texts, then, a balance must be struck between reading them as forwarding philosophical theories - theories that are argued for and defended - and as forwarding prescriptions for the treatment of philosophical disease.

The exploration of Stoic moral practice in this essay has been tied to observations about practices in Buddhism, and my central focus has been on identifying passages of text that recommend moral practices. I hope, however, that this essay can provoke a greater interest in a different kind of comparative philosophy. Many comparative studies today utilize Western philosophical sources to understand non-Western sources. This work has been quite productive and has in many ways reshaped our understanding of philosophy. Equally important, however, is to identify those components of non-Western philosophical schools that can enrich and enhance our understanding of Western philosophies. The work I present here is meant to be a small step in that direction.

\section{ACKNOWLEDGEMENTS}


I would like to thank an anonymous referee from Comparative Philosophy for an extensive and very helpful set of comments.

\section{REFERENCES}

Annas, J. (1995), The Morality of Happiness (New York: Oxford University Press).

Appiah, K. A. (2007). Cosmopolitanism: Ethics in a World of Strangers (New York: W.W. Norton \& Company, Inc.).

Aurelius, Marcus (2003), Marcus Aurelius, trans. C.R. Haines (Cambridge, MA: Loeb Classical Library of Harvard University Press).

Buddhaghosa. Visuddhimagga, trans. B. Namamolid (1975), The Path to Purification (Kandy, Sri Lanka: Buddhist Publication Society).

Blundell, M. W. (1990). "Parental Nature and Stoic Oikeiōsis," Ancient Philosophy 10.2: 221-42.

Cicero. De Finibus trans. E. M. Atkins (1991), On Duties (Cambridge: Cambridge University Press).

Dalai Lama, His Holiness (2005), How to Expand Love: Widening the Circle of Loving Relationships (New York, NY: Atria Books).

Engberg-Pedersen, T. (1990), The Stoic Theory of Oikeiōsis (Aarhus, Denmark: Aarhus University Press).

Epictetus. The Discourses of Epictetus, trans. R. Hard, ed. C. Gill (1995) (London: Everyman Library).

Frankfurt, H. (2004), The Reasons of Love (Princeton, NJ: Princeton University Press).

Frederickson, B. L., Cohn, M. A., Coffey, K.A., Pek, J., \& Finkel, S.M. (2008), "Open Hearts Build Lives: Positive Emotions, Induced Through Loving Kindness Meditation, Build Consequential Personal Resources", Journal of Personality and Social Psychology 95.5: 1045-62.

Gill, C. (2006), The Structured Self in Hellenistic and Roman Thought (Oxford: Oxford University Press).

Hadot, P. (1981), Exercices Spirituels et Philosophie Antique, trans. M. Chase (1995). Philosophy as a Way of Life (Oxford: Oxford University Press).

Hadot, P. (1995), Qu'est-ce que la Philosophie Antique? Trans. M. Chase. (2002). What is Ancient Philosophy (Cambridge, MA: Harvard University Press).

Harvey, P. (2000). An Introduction to Buddhist Ethics: Foundations, Values, and Issues (Cambridge: Cambridge University Press).

Harvey, P. (2007), An Introduction to Buddhism: Teachings, History, and Practice. (Cambridge: Cambridge University Press).

Helm, B. (2010), Love, Friendship, and the Self: Intimacy, Identification, and the Social Nature of Persons (New York, NY: Oxford University Press).

Holiday, R. (2016), Ego is the Enemy (New York: Portfolio / Penguin).

Irvine, W. (2008), A Guide to the Good Life: The Ancient Art of Stoic Joy (Oxford: Oxford University Press).

Karaniya Mettā Sutta (Snp 1.8) trans. Thanissaro Bhikku. (2004), “Access to 
Insight," $<$ http://www.accesstoinsight.org/tipitaka/kn/snp/snp.1.08.than.html >.

Keown, D. (2013), Buddhism: A Very Short Introduction (New York: Oxford University Press).

Kleingeld, P. \& Brown, E. (2013), “Cosmopolitanism," in Stanford Encyclopedia of Philosophy: < http://plato.stanford.edu/entries/cosmopolitanism/>.

Kornfield, J. (2002). The Art of Forgiveness, Loving-Kindness, and Peace (New York, NY: Bantam Dell).

Mills, E. (2004), "Cultivation of Moral Concern in Therevada Buddhism: Toward a Theory of the Relation Between Tranquility and Insight", Journal of Buddhist Ethics 11: 20-46.

Nagel, T. (1986), The View from Nowhere. (New York: Oxford University Press).

Nehamas, A. (2000), The Art of Living (Berkeley, CA: University of California Press).

Nussbaum, M. (1994), The Therapy of Desire (Princeton, NJ: Princeton University Press).

Nussbaum, M. (2002), For Love of Country (Boston, MA: Beacon Press).

Pembroke, S. (1971), "Oikeiōsis", in Problems in Stoicism, ed. A. A. Long (London: Athlone Press).

Salzberg, S. (2002), Lovingkindness: The Revolutionary Art of Happiness (Boston, MA: Shambhala Publications).

Seneca, Epistulae Morales, trans. R. Gummere (2002), Moral Letters (Cambridge MA: Loeb Classical Library of Harvard University Press).

Seneca, De Otio, trans. J. Basore (2006), Moral Essays, Vol. II (Cambridge, MA: Loeb Classical Library of Harvard University Press).

Sellars, J. (2006), Stoicism (New York: Routledge).

Singer, P. (2011), The Expanding Circle (Princeton, NJ: Princeton University Press).

Sorabji, R. (2000), Emotions and Peace of Mind: From Stoic Agitation to Christian Temptation (New York: Oxford University Press).

Sorabji, R. (2005), Self: Ancient and Modern Insights about Individuality, Life, and Death (New York: Oxford University Press).

Stockdale, J. (1993), Courage Under Fire: Testing Epictetus' Doctrines in a Laboratory of Human Behavior (Stanford, CA: Hoover Institution Press).

Wolf, S. (1992), "Morality and Partiality", Philosophical Perspectives 6: 243-59. 